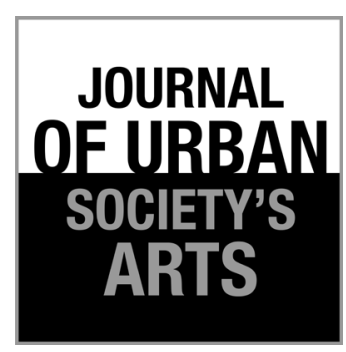

Volume 6 Nomor 1, April 2019: 39-55

\section{Glundhângan and Pigeon in Sociocultural Practices of Madurese People}

Panakajaya Hidayatullah

Faculty of Cultural Science, University of Jember

Jalan Kalimantan No. 37, Jember Regency, East Java 68121

E-mail: panakajaya.hidayatullah@gmail.com

\begin{abstract}
ABSTRAK
Glundhângan adalah ansambel gamelan kayu yang dimainkan oleh orang Madura. Musik glundhângan dipercaya sebagai musik kuno orang Madura. Bahkan ada sebelum era gamelan metallophone. Di Jember, glundhângan terkait erat dengan merpati dan biasanya digunakan untuk acara nyata dan tottáan dhârâ. Nyata adalah peristiwa ketika master merpati berhasil mendapatkan merpati lawannya. Sementara tottaian dhârâ adalah pertandingan melepaskan merpati bersama dan kemudian mereka, merpati, kembali ke pajhudhun (rumah merpati) dari tuan mereka. Glundhângan adalah musik yang menjadi penanda kemenangan master merpati ketika ia mendapat merpati lawannya, dan itu adalah musik yang menyertai pelepasan merpati dan kembali ke rumah. Glundhângan terdiri dari beberapa alat musik kayu seperti glundhâng, dhung-dhung, tong-tong, tek-tek, nèng-nèng dan ghâghâmbhâng, dan mereka disertai oleh vokal dari tembhäng mamaca (versi kuno) dan kèjhungan (versi modern). Setiap pajhudhun dan merpati harus memiliki alat musik dhung-dhung atau tong-tong dalam bentuk berbagai kentongan yang terbuat dari kayu. Alat musik digunakan oleh seorang master sebagai alat komunikasi untuk merpati dan manusia. Instrumen dhung-dhung dari master merpati umumnya keramat sebagai peninggalan lainnya seperti keris. Pada umumnya, sang guru memasok dirinya sendiri dan merpati dengan kekuatan mistis. Ini adalah dhung-dhung itu sendiri yang menjadi identitas musik glundhângan. Bagi orang Madura, merpati diperlakukan sebagai hewan istimewa. Merpati juga merupakan perwujudan kekuatan supernatural dari tuannya. Musik dan merpati glundhângan adalah artikulasi orang Madura yang mewakili tingkat sosial, kebanggaan yang dipertaruhkan, simbol maskulinitas dan distribusi hasrat konflik yang produktif di antara orang-orang.
\end{abstract}

Kata kunci: glundângan; totta'an dhârâ;; orang Madura; Jember

\section{ABSTRACT}

Glundhangan is an ensemble of wooden gamelan played by Madurese people. Glundhangan music is believed as archaic music of Madurese people. It even existed before era of metallophone gamelan. In Jember, glundhangan is closely related to pigeon and usually used for nyata and totta'an dhârâ events. Nyata is an event when a pigeon master succeeds to get his opponent's pigeon. While totta'an dhârâ is a match of releasing pigeons together and then they, pigeons, come back to pajhudhun (pigeon house) of their masters. Glundhângan is a music which becomes winning signifier of pigeon's master when he gets his opponent's pigeon, and it is an accompanying music for pigeons release and return to home. Glundhângan consists of some wooden musical instruments like glundhâng, dhung-dhung, tong-tong, tek-tek, nèng-nèng and ghâghâmbhâng, and they are accompanied by vocal of tembhâng mamaca (ancient version) and kèjhungan (modern version). Every pajhudhun and pigeon master must have musical instruments dhung-dhung or tong-tong in a form of various kentongan made by wood. The music instrument is used by a master as means of communication to pigeons and people. Dhung-dhung instrument of the pigeon master is commonly sacred as other relics like keris. Commonly, the master supplies himself and pigeons with mythical power. It is dhung-dhung itself which becomes identity of glundângan 
music. For Madurese people, pigeon is treated as special animal. Pigeon is also a manifestation of supernatural power of its master. Glundhângan music and pigeons are articulations of Madurese people that represent social degree, pride at stake, symbol of masculinity and productive distribution of conflict desire among people.

Keywords: glundângan; totta'an dhârâ; Madurese; Jember

\section{Introduction}

Music instruments cannot be separated to Madurese people tradition in case of social relation. Almost in every event, social meeting, ritual and custom celebration, social gathering and other social activities, it is common to know and inform some or all people in form of ordinary sounds (sound speaker or music instruments), or in form of composed sounds (music) (Bouvier, 2002: 39), likewise tradition of raising pigeon which for Madurese people is called dhârâ ghettakan. Dhârâ ghettakan is a kind of pigeon with crest. A term ghettakan in Indonesia language means 'snap', which means that this bird usually flies by being snapped. There are many terms/names in various areas, like in Situbondo, it is called dhârâ abbhrâghân, in Madura island, it is called dhârâ ghettaghân and dhârâ ghunjhi. Tradition of raising dhârâ gettakan is often related to music activities because it is identical to the use of ancient music instrument tong-tong/kentongan and a traditional music ensemble called glundhângan.

Every master of dhârâ gettakan commonly has tong-tong instrument (small bamboo kentongan) or dhung-dhung (big bamboo kentongan). The use of those instruments is functioned as means of communication between master and his pigeon, and among masters of dhârâ gettakan and also people around. In case of relation to pigeon, tongtong is sounded when a master calls his lost pigeon or it flies too far, or as ritual in a night to make pigeon fly higher. In relation to people, tong-tong is sounded as winning signifier for glorification or information to local people that a master has succeeded to get opponent's pigeon.

Tong-tong iconic instrument of dhârâ, in certain moments, is played in ensemble with some other wooden instruments. This ensemble is known as glundhângan. Glundhângan is an ensemble of wooden gamelan regarded as ancient and archaic because it is rarely founded. Brandts Buyz-Van Zijp (1928: 50-55) in Bouvier (2002: 54) also writes about an instrument similar to "primitive" xylophone in Madura called ghâloendhâng. A term glundhângan comes from a word glundhâng which refers to an ancient wooden instrument with lath. Its form is similar to xylophone instrument in Java but it has lesser lath of tone. Bouvier explains that glundhângan music in Madura has similarity with okol music which also consists of set of wooden gamelan. If it is seen from music composition, Bouvier assumes that the wooden gamelan music is a legacy of ancient culture of Madurese people, who tries to be modern today with its orientation to play compositions of metallophone gamelan and new gending/song (Bouvier, 2002: 52). A bit different to Bouvier, Setiawan (2018) argues that glundhângan music is an imagination of 'grassroot' people of gamelan keraton (palace). In composition, works of glundhângan music today are closer to metallophone music of gamelan.

In tradition of dhârâ gettakan, glundhângan music is played when a master plays 'nyata' event. Nyata is a moment when a master succeeds to get opponent's pigeon and in a night, he wants to hold an event of celebration by inviting his colleague masters. They usually join village groups/ paguyuban of pigeons. Nyata can be interpreted as an information for public that there is a pigeon master who succeeds to get opponent's pigeon. In this moment, glundhângan music is played. Besides in nyata event, glundhângan is played in other public events related to dhârâ gettakan like totta'an (match event among groups of pigeon) and arisan dhârâ (gathering of pigeon masters in a group)

In Madura, especially in Rubaru, Sumenep, tradition of raising dhârâ gettakan is a part of people's life for a long time. Ihsan, a master of dhârâ gettakan, tells his experience.

I raise pigeons because of ancestors' legacy, handed down by my ancestors 
in the past. Since keraton era, this tradition, I think, has been existing. If in a house, there is pigeon pet, it will not be disturbed by demons. Pigeon is not easy to be influenced by prayer or supernatural power, because it sleeps with one leg. If it is influenced by evil forces, it will not succeed. A person who raises pigeons will tirakat, does not sleep every night, follows his pigeons' habit. Standing with one leg signifies supernatural power, sometimes if a master is strong, he will tirakat standing with one leg.

... When getting opponents' pigeon, a master must hide kentongan/dul-gudul, (winning signifier), the loser who loses his pigeon must be 'burning' (emotional and feels ashamed) because besides loosing pigeons, he feels mocked and ashamed with music play. Here in the past, when there is a winner who gets pigeon, gathering or tottain event must be crowded, there is gamelan music (glundhângan), completed with tong-tong, dhung-dhung, ghung (gong), saronen, canmacanan and lady singer. (Ihsan, personal communication, in 31 ${ }^{\text {st }}$ December 2019 in Rubaru, Sumenep, Madura)

Ihsan statement explains that tradition of dhârâ gettakan has been existing for long time in Sumenep. He also explains that pigeon is a special animal and can give speciality of its owner. Raising pigeon is closely related to art activity and sociocultural practices of Madurese people.

Tradition of dhârâ gettakan does not only develop in Madura island, but also in some areas in Java island, especially in some migration area of Madurese people in east parts of Java island, which are Situbondo, Jember, Bondowoso and Lumajang. Madurese people who migrate to east parts of Java island also bring their origin culture to a new area. Therefore, it opens possibility to have process of assimilation and dialectics with other culture existing in the area like Java, Tionghoa, Arab and Osing. In migration area, tradition of dhârâ gettakan and its art instruments develop with dynamic of diverse and different culture from Madura island. Culture style in every migration area is quite diverse. In Situbondo, most of people are Madurese migrants from Sumenep (See, Husson, 1997; dan Hidayatullah, 2017). Tradition of dhârâ gettakan (in Situbondo called dhârâa abbrâghân) is almost the same with in Sumenep, but glundhângan art does not exist anymore. It is replaced by saronen art (Fauzi, personal communication in $5^{\text {th }}$ janiary 2019, in Pokaan village, Kapongan, Situbondo), likewise in Lumajang in which most of people are Madurese migrants from Pamekasan and Sampang (See, Husson, 1997). Art used in dhârâ gettakan tradition is an assimilative art like jaranan, reog or patrolan (Based on observation to some lottery event of dhârâa ghettakan in Rowokangkung, Nogosari, and Kalipepe (Yosowilangun), Lumajang in $6^{\text {th }}$ and $20^{\text {th }}$ January 2019). In hinterland Bondowoso, tong-tong-an art in nyata still exists and is preserved, but ensemble of glundhângan is rare and hard to find.

Different from some migration areas above, in Jember, tradition of dhârâ gettakan with glundhângan music still exist and live together with multi culture society. Based on its history, Jember is a destination area of migration of Madurese people from Pamekasan and Sampang (See, Husson, 1997; dan Prasisko, 2015: 12). Migration of Madurese people to Jember is mostly based and motivated by land clearing for plantation and establishment of tobacco company in colonial era (Arifin, 2006). In Jember, glundhângan art still can be found in some areas like plateau Sokma Èlang, Panduman, and Soca Pangepok, and suburbs area like Kebonsari and Antirogo (Refers to data written by Palmer Keen in website auralarchipelago (accessed in $12^{\text {nd }}$ December 2018). Existence of glundhângan in Jember can survive maybe because of available materials for making instruments which are various kinds of wood. Some glundhângan players evenly make its instruments by themselves with wood from a tree they plant (Kernet, Iral and Ju' Salam, personal communication in $27^{\text {th }}$ December 2018). Besides, in Jember there are also craftsmen of wooden music instruments who can make glundhângan instruments as ordered. As close relation between tradition of dhârâ gettakan and glundhângan music, existence of the music can also survive because many people conserve tradition of 
raising dhârâ gettakan. In Jember we can see clearly how crowded people who raise pigeons. This can be seen from many pajhudhun (dhârâ gettakan house) in Jember.

Focus of this research is phenomena of tradition of dhârâ gettakan and glundhângan music in relation to sociocultural practices of Madurese people. Subject of research is focused on two glundhângan groups and pigeon communities in two different locations which are Soca Pangepok and Jember city area (Keranjingan-Kebonsari). These two subjects are used to look complexity of data and phenomena in Jember. It needs to explain that glundhângan group in Soca Pangepok is still categorized as traditional and characterized as Madurese dominant, while in Jember city area, glundhângan group has assimilative character and is melted with culture style of Java and Osing. Therefore use of the two subjects of research is important to elaborate deeply to get comprehensive study.

This research discourses Clifford Geertz theory about interpretation of culture. Geetz makes a concept and perspective of culture in anthropology research. There are some offered concepts. First, Geertz (1992: 5) offers concept of interpretative culture, a semiotic concept in which he sees culture as a text which needs to interpret its meaning rather than as pattern of concrete behavior. Concretely, Geertz defines culture as

"A system of meaning and symbol arranged in the meaning of individuals who define their world, state their feeling and give valuations; a pattern of meaning transmitted historically manifested in symbolic forms in which people communicate, perpetuate and develop knowledge and attitudes to life direction; a set of symbolic equipment to manage behavior, source of extrasomatic information" (Kuper, 1999: 98)

From the explanation above, it can be said that culture is a network of meanings, culture is not something visible, but it exists behind visible things.

The first concept gives introduction to the second concept which is "culture as a text". As a text connected to network of symbolic meanings, it needs deep and comprehensive interpretation of cultural subject. In this case, Geertz offers a perspective to analyze it, by borrowing a term from Gilbert Ryle, "thick description" (Geertz, 1992: 6). Generally, thick description is a deep description, an approach to understand, interpret and explain symptom, phenomena, idea and sociocultural habit accentuating depth of data of various aspects which are often 'odd', disorder even invisible/implicit.

The third concept is about metaphor. Geertz develops theme of metaphor in his interpretation of anthropology to analyze cockfight in Bali. "Geertz introduces metaphor as a kind of art including other meanings which make daily life easy to 'read' in reproduced form rather than in unmanifested thing" (Prasisko, 2015: 37). According to Geertz, culture is also contextual and contains public meaning. Geertz gives an example of cockfight in Bali "Poetry makes nothing happen,"Auden says in his elegy of Yeats, "it survives in the valley of its saying ... a way happening, a mouth. "The cockfight too, in this colloquial sense, makes nothing happen" (Geertz.,C., 1973:443). Poetry and cockfight are only media of articulation, they promise freedom to overcome limited social condition. In cockfight, those who fight are not only cock, there is implicit meaning behind. There is multi-interpretation inside, like pride at stake, dignity, position, caste, social status etc. A kind of contestation of pride is limited by social condition and custom norm. Therefore cockfight becomes media of articulation to release violence expression. Interpretation of culture theory by Clifford Geertz is used to look relation between pigeon and human, and interpret practices of glundhângan group when interacting in group of people.

To read interaction/social system through glundhângan music, it is also used theory of socialcultural practices by Pierre Bourdieu. To read interaction between social agent and social system through glundhângan music, it is also used theory of social-cultural practices by Pierre Bourdieu. For Bourdieu, social practice is related to culture. Social actor performs in social arena to achieve certain goal, the actor improves and corresponds to social system. Cultural factor is shown through how practice needs mastery. Mastery of practice comes from cultural background about how a 
skill is deduced, learned and taught. There are two factors underlying cultural practice which are educational (formal or informal) capital and social origin (Bourdieu, 1984:13). Education may come from cultural teaching of family. Therefore, sociocultural practice is a reading of mastery of practice, agent interest, situational constraint, available means, personal idiosyncrasies and history of individuals relationship in particular social field.

\section{Pigeon in Madurese Tradition}

In tradition and culture of Madurese people, raising pet is not only for livestock, but there are often other intentions behind. Like most of Madurese people are known as cow keeper (Jonge, 2011: 88). Raising cow especially bulls has the same meaning with raising buffalo for Javanese people, or cock for Balinese which means symbol of power and prosperity. Not only cow treatment, Madurese people also have unique tradition about their closeness to animal, one of them is pigeon, especially dhârâ ghettakan.

Dhârâ ghettakan is a species of pigeon with crest which is living in colony. Sometimes, there are also those who use post pigeon. Madurese people call it dhârâ rèsing (racing) for its high speed in flying. It is called dhârâ ghettakan because this bird usually flies by being snapped (ghettak). Tradition of raising pigeon for Madurese people is believed giving many benefits. Ihsan as a master of ghettakan pigeon in Rubaru, Sumenep, Madura says that raising pigeons can protect a house from demons attack. Ihsan believes that "mon bâdâ dhârâna nèka ta' patè è pernaè jin" (If there are pigeons in house, demon will not survive). Pigeon, for him, can ward evil forces of demons (Ihsan, personal communication in $31^{\text {st }}$ December 2018 in Rubaru, Sumenep, Madura). Ihsan statement is based on his experience for years. Pigeon is belived as bird which has magical power because of its uncommon habit when sleeping. By Madurese people, it is called soko nongghâl (sleeping with one leg). This pigeon habit is then related to spiritual work of human standing with one leg. This spiritual work, standing with one leg, signifies that the man has supernatural power.
Another statement told by Fauzi who is a pigeon master and a chief of pigeon community in Pokaan village, Situbondo regency. Here is his experience story during raising ghettakan pigeons.

"I raise pigeons because of ancestors' legacy... Pigeon is different from other animals. How do I say, pigeon is actually like human, it can communicate. Kiyai Kholil has invited me three times, inviting pigeon community. Kiyai Kholil raises many pigeons about a hundred pairs. When feeding pigeons, Kiyai sit on small chair while open a holy book about pigeon chapter. He then gives lecture to his students: 'so that you know, this pigeon is different to pigeon race (ando'an), when sounding in a night, past 12 o'clock, that means the pigeon prays for people around and neighbor, especially prays for its raiser." (Fauzi, personal communication in $5^{\text {th }}$ January 2019, in Pokaan village, Kapongan, Situbondo).

For Fauzi, raising pigeon is believed to be able to give blessing. He believes that what is said by Kiyai Kholil (based on reading holy book) is true, like he feels. KH. Kholil As'ad is a well-known Kiyai and has strong influence in Situbondo. He is a son of KH. As'ad Syamsul Arifin. KH. Kholl As'ad is a caregiver of Walisangan Islamic Boarding School in Mimbaan, Panji, Situbondo. For people, $\mathrm{KH}$. Kholil is knows as controversial figure because he often pemits cockfight in Islamic Boarding School and has rombongan tabbhhuwân (a group of ketoprak). During raising pigeon, Fauzi always feels happy and excited. For him, pigeon is like his family, so good treatment to pigeons will also get good result (Fauzi, personal communication in $5^{\text {th }}$ January 2019, in Pokaan village, Kapongan, Situbondo).

Besides it is believed to give blessing and supernatural protection, pigeon also means as symbol of degree and prestige. There is ancient idiom often uttered by some informants I meet about pigeon, which is "ngobu dhârâ mon ontong bisa maongghâ dhârajhât, mon apes bisa dhârâka" (raising pigeon, if lucky, can increase degree but otherwise, it can be perfidious. This idiom explains that raising pigeon is actually risky because if we 
succeed to raise, we get high degree, but otherwise if we fail to treat and raise, we will get bad luck (perfidious) (Budi, personal communication in Kalisat, Jember, in $22^{\text {nd }}$ January 2019). In case of relation between pigeon and someone's degree, maybe it can be seen from a philosophy believed by most of Javanese people, including Madurese. In tradition in the past, high or low degree of people is measured by achieving life success. A benchmark is through achievement of having eight worldly aspects which are 1) work/job, 2) garwa/wife, 3) wisma/house, 4) curiga/keris/weapon and relic, 5) turangga/ride 6) kukilabird pet, 7) warangganal lady singer, 8) pradanggalgamelan (Santosa, 2017: 15). In that philosophy, pigeon is a symbol of manifestation of kukila/bird pet for Madurese people. Like privilege of turtledove for Javanese people, it is always related to spiritual power. Even though, in today context, many Madurese people also raise other birds like love bid, but it is only for entertainment, business and pleasure, which is different context for raising pigeon which has spiritual value.

Most masters of ghettakan pigeon among Madurese people are men. They treat pigeon like treating their family. There are special treatments about buying and raising ghettakan pigeon. Here are some treatments by master for his pigeons told in some ethnographic notes:

"In an afternoon, 22 $2^{\text {nd }}$ January 2019, Mas Budi takes me to Mr, Salam's house to buy a pair of pigeons. There are many specified criteria by mas Budi in choosing pigeons like type of fur color, pigeon physic and the most important thing is how 'pelak' (loyal) pigeon bought to its former master. A pigeon which looks loyal will be avoided to buy because it will not stay long in a new house and mostly it will be back to its former master. Mas Budi specifies loyal degree of pigeon through his feeling. A pigeon which sleeps with soko nongghâl (one leg) must have high loyal degree to its former master. Besides, pigeon which is usually loyal to its former master will not want to eat food in which prayer of affection is blown. According to mas Budi, raising ghettakan pigeon is better beginning from baby (pejji), because it is easier to train its loyalty. Besides, pigeon treated from baby tends to be more loyal rather than raising when adult" (Ethnographic note in $22^{\text {nd }}$ January 2019 in Kalisat, Jember).

Before buying pigeon, a master will choose pigeon which is not only health physically but also mentally. The master and his pigeon are commonly related by inner connection. Pigeon which has strong inner connection with its master will be difficult to separate even though it moves to a new master (sold). Because in some cases, many pigeons just bought then fly away to return to his former master. Therefore choosing pigeon is also determined by level of its loyalty to his former master.

Establishing new house for pigeon (pajhudhun) is like establishing new house for human. There are process and steps like looking for a good day, considering position and direction of pajhudhun, looking for ritual terms which must be put in establishing pajhudhun like salèmpet (kinds of plant roots believed as affection amulet), bâto ghilis (corn mill believed to strengthen pajhudhun), sobbhul (relic), keris and other relics. The process must be done so that later there will be no bad things happening to pigeons and its pajhudhun and be a self-protection from evil forces (ajâgâa $a b \hat{a})$.

Pigeon just bought cannot be raised as usual in a cage, but there are special treatments by its master. Here are some special treatments by mas Budi to some new pigeons he just buy.

"Pigeon, mas Budi just buy, is placed in pajhudhun (pigeon house) with its fur partially tied (ghudhi). For a week, the pigeon is caged in pajhudhun. After that, tie is loosened (è anyarè) while reading mantra (prayer). When loosening, underarm fur of the pigeon is pulled out then planted/put in its pajhudhun to make it feel at home. This process is mostly accompanied by celebration ritual. The next process is master's approach to pigeon. In this step, mas Budi tries to be close to his pigeon by regularly feeding, food and drink, communicating and giving jhepah/ sellekkan (mantra and affection prayer). 
Mantra and prayer red are affection prayer (mahabbahlpelet) usually used among humans" (Ethnographic note in Januari 2019 in Kalisat, Jember).

The most important thing to raise pigeon is having inner connection with it. Success of raising ghettakan pigeon is measured by how loyal the pigeon to its master. To steal pigeon's attention, most masters will use mantra and affection prayer, the same prayer usually used among humans. The mantra or prayer are dhâddhâli potè poter ghiling and Yusuf letter (Intensive observation and interview with mas Budi as a master of ghettakan pigeon in $30^{\text {th }}$ January in Kalisat, Jember). In daily context, this mantra and prayer are usually used to influence person to make him/her love the mantra reader. Affection power is commonly used because of denial or insult of a target to the mantra reader. Some informants say that mantra and affection prayer for pigeons has higher degree of difficulty rather than for humans. Therefore a pigeon master who has subdued his pigeon or other people's pigeons will be believed to have high affection power by people.

Every pigeon master is connected each other. As ghettakan pigeons which live in colony, their masters also live in colony and form groups/ communities. Commonly, in every village in Jember, there is one or more communities of ghettakan pigeon. Every pigeon community is led by a chief chosen by mutual agreement. Names of community chief of ghettakan pigeon are different in every place. In Situbondo and Jember, a chief is called jhârâghân, while in Lumajang called ghunongan. Most chiefs of community are chosen based on personal prestige, high knowledge and enough experience in winning match of dhârâ ghettakan. Every chief is responsible for members when competing among communities.

Every community holds regular meeting every week with arèsan concept (gathering with each member takes a turn as host), as arèsan group of white pigeon community led by Mr. No in Keranjingan-Kebonsari Jember.

"I am given a mandate as a chief since 2003 until now. Many people joined, but now many quit. Now, every member usually joins five arisan, maximum is about 30's people. When getting a turn, a host can get a million three hundred thousand rupiah. In the past, it achieved 15 million. Members who join must bring at least 6 birds. This arisan must exists, said friends, to make them not bored. Besides place of gathering, there is also a bonus" (Pak No, personal communication in $30^{\text {th }}$ December 2018 in Keranjingan, Jember).

In arisan event, every pigeon master in one community must bring 3 pairs of pigeons (6 pigeons). These pigeons are then released together after arisan lottery. A lucky master who gets arisan lottery will be a host in next arisan. Arisan event is not separated to accompanying music of dhârâ ghettakan which is glundhângan. While waiting a peak of the event, some masters come to sing and alternately play the music. Arisan and glundhângan music sounds are broadcasted to all over a village by using loudspeaker installed with 3-5 meter height as high as pigeon pajhudhun. Even if this arisan is gathering space among communities, but when event of releasing pigeons, there is also competitive nuance among pigeon masters. The rule is when pigeons are released, actually they has been nobody's so that competition of loyalty to their master is determined when releasing together. Loyal pigeon to its master can return to its pajhudhun. Therefore a master will also get respect from other masters because he is believed to have high knowledge to make his pigeon loyal. Meanwhile, pigeon which cannot return home and join other pigeons' colony of another master is not loyal. Its master will feel ashamed because he cannot have loyal pigeon. It also signs that he loses with a power of another master which brings his pigeon. Therefore, even in arisan community context, competitive nuance is still strong. There are even some masters who admit that before arisan comes, he has trained his pigeons for some days to make them return to their pajhudhun, and prepared/sharpened his inner power last night before the arisan event (Pak Taufik and Edi, personal communication in $30^{\text {th }}$ December 2018 in Keranjingan, Jember).

Tradition of raising pigeon is also related to series of match which are must to follow by every master and pigeon group/community, like 
tradition of raising cow full of competition like karapan sapi (cow race), aduan sapi (cow fight) and sapi sono' (cow beauty contest). According to Bishop (1925), animal match is a part of people's ritual about land fertility and productivity. Like many animal matches in Indonesia (including Madurese cow fight), animal fight is always for pleasure of God of rain. Kreemer (1956: 89-90) states that cow fight match in east Java is actually held to signify transition of rainy and dry season. In Jember, tradition of releasing dhârâ ghettakan (totta'an dhârâ) is also closely related to ritual activities, Like every village celebration event (cleaning village), and wedding ceremony, tradition of releasing ghettakan pigeon is always a must for Jember people (Observation in village celebration (kathisa) in Sumbersalak village, Ledokombo and interview with $c a k$ Lip in $11^{\text {th }}$ January 2018 in Sumbersalak, Ledokombo, Jember). Ritual archetype in tradition of ghettakan pigeon can be sorted to be some parts, like ritual of establishing pajhudhun, installing gudhi (tie to wings), releasing gudhi, training pigeon, elevating pigeon, marrying pigeon, calling pigeon, preparing totta'an dhârâ match, the match itself and nyata celebration. It is the same like tradition of Madurese people in raising cow fighter. The different is that there is no pigeon blood sacrificed in ritual (see Jonge, 2011: 92-93). For completing ritual celebration, a master will usually sacrifice other animals like chicken. Pigeon's blood is rarely shed, only once when pulling out its underarm fur when the pigeon gudhi will be released.

In tradition of dhârâ ghettakan in Jember, there are two kinds of match which are system of lottery (invitation) and tottáan dhârâltompoan. A match with system of lottery is usually hold by individual or group (government) by inviting some pigeon communities from villages. In that event, there will be doorprize like goat, refrigerator, electric fan, motorcycle etc. The match with system of lottery is usually held at certain moments like Independence Day, $17^{\text {th }}$ August 1945, village celebration and political campaign. Every community invited is gathered in wide match arena (usually field). A peak of the event is releasing all pigeons brought by all community members. The end of event is closed with doorprize and entertainment. In the match with system of lottery, competitive nuance is not too strong and hot because there are too many participants who compete, so it is difficult to detect the winner and loser.

The second type of match is Tottaian dhârâ which is a duel match between two pigeon groups. The match is held alternately with home and away system in a place decided based on two groups agreement. Usually, the two groups dueling come from different villages like community from Soca Pangepok versus Arjasa village. Totta'an match is done through agreement of two communities that decide how many ghettakan pigeons are brought by each community, totta'an location and other rules related to technical rules. A winner will be decided based on how strong a community holds total of pigeons who return to their own pajhudhun. A community which loses many pigeons or fails to return pigeons to his pajhudhun, culturally, becomes a loser. Otherwise, a community that is strong to hold its pigeon or maybe succeeds to seize opponent's pigeons will be a winner. In this case, decision for winner is again decided by how loyal pigeon to its master. A master who succeeds to get opponent's pigeons, culturally, will get award from people. This means that he can conquer his opponent. An event of getiing oppnent's pigeons will be signed by nyata, a celebration event to welcome new pigeons just got as a new family. Nyata is enlivened by glundhângan music and attended by all community members to welcome a victory as well as signifier to people around that there is a master who has succeeded to get pigeons. It also aims to heat up a conquered opponent (Ju' Salam and Sup, personal communication in $29^{\text {th }}$ December 2018 in Soca Pangepok village, Jember). The master who holds nyata will get respect from local people. Commonly, he is respected by people related to his affection knowledge because he is believed to have high affection power.

Therefore, symbol of masculinity in match of ghettakan pigeon is different to symbol of masculinity in match of cow race for Madurese people or cockfight for Balinese people. In totta'an dhârâ, there is no money gambling or physical fight of male animal but it is a fight of loyalty strength 
between pigeon and its master. If cow and chicken represent symbol of masculinity, then pigeon in tradition of tottaian dhârâ represents symbol of feminism. Treatment and use of affection mantra to ghettakan pigeon signify that pigeon in mindset of Madurese people is put as symbol of feminine. It is different to cow position in context of cow fight or cow race. Effort of Maurese people to subdue pigeon signed by obedience and loyalty is domination attitude of masculinity of Madurese man to feminine pigeon. Relation between Madurese man and ghettakan pigeon is manifestation of masculinity side of Madurese people. Pigeon is actually media used by Madurese people to show power of affection knowledge. In totta'an dhârâ, the real fight is among masters who fight their affection knowledge. The higher knowledge of affection, the bigger chance for pigeon to return to its pajhudhun and win a match.

\section{Glundhângan Music as Medium of Communication}

In tradition of dhârâ ghettakan, music is integral medium and also becomes an important part in various moments and events. There are many kinds and music naming related to tradition of dhârâ ghettakan, but most Madurese people know the music with a name, glundhângan. The ensemble naming refers to one of wooden instrument similar to xylophone, which is glundhâng. Instrumentally, Munardi (1983:32) in Bouvier (2002: 54) notes that,

"Principally, glundhâng is also gamelan set, but its material instrument is not metal. Almost all materials are from bamboo and wood. Laths or pencon is replaced by wooden laths. So it is similar to kolintang. For kendang, it makes instrument like kentongan, which is short log given hollow and mouth in its sides. The instrument is called dhuk-dhuk or thuk-thuk".

In Madura island, this kind of ensemble with wooden gamelan like glundhângan has many names which are okol, an ensemble of wooden gamelan consists of musical instruments, tong-tong (wooden kentongan), ghambhang (same kind with xylophone), small cymbal and flute. Okol orchestra is usually played in fight event of kèkèt or okol (same kind with wrestling) and ojhung (fight by using rattan). Okol orchestra is also usually used to accompany event of pigeon race (Bouvier, 2002: 50).

Besides okol, there is also another name for a kind of wooden gamelan like glundhângan which is Ghul-Ghul, an ensemble of wooden gamelan which consists of tong-tong (wooden kentongan). saronen ghambhang (xylophone), flute, kerca and peking. Functionally, ghul-ghul ensemble has similarity to glundhângan music which is for accompanying pigeon event (Irmawati, 2004: 54). In Proppo sub-district, Pamekasan district, there is also ensemble like glundhângan and ghul-ghul named tabbhuwân Gebbluk. Instrumentally, they have many similarities which uses wooden kentongan. The difference is gebbluk music adds kennong tello' instrument (three kenong) and serbhung.

From some kinds of ensemble name above, all has same function which is used to accompany pigeon event and from all kinds of ensemble, there is a same instrument which is tong-tong or dhung-dhung (wooden and bamboo kentongan). Before discussing function and role of glundhângan ensemble completely, it will discuss first role of tong-tong/dhung-dhung instrument, remembering that this instrument is important and becoming icon of glundhângan ensemble.

Tong-tong comes from copy of sound (onomatopoeia) of music instrument made by wood or bamboo punched its center as resonance

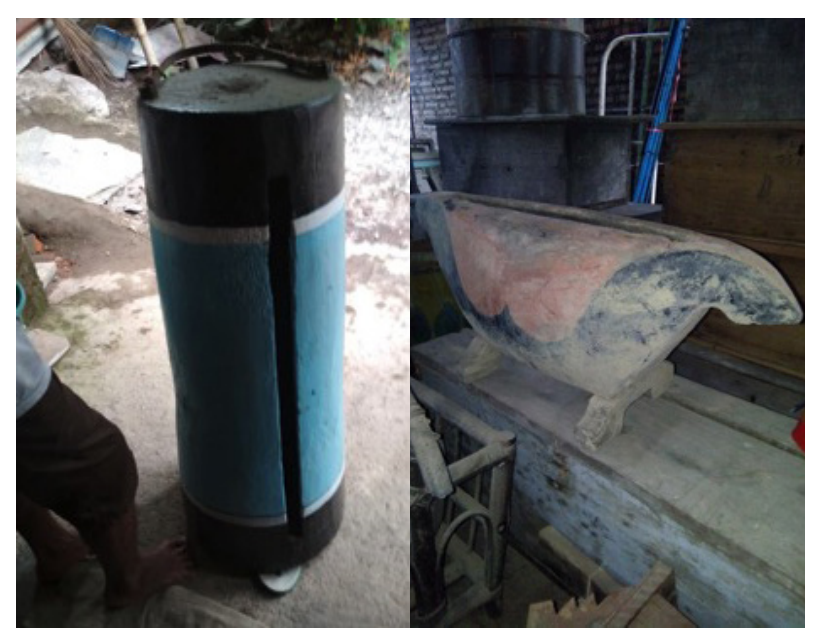

Figure 1. Dhung-dhung (left) and tong-tong ghellung (right). (Source: Budi Kalisat documentation) 
space. This instrument is like kentongan usually used by Javanese people for night watch and as communication tool in the past, for danger sign. In Madurese people, tong-tong instrument is usually used for many functions which are as instrument in patrol orchestra which functions to wake people up to sahur (eating in predawn for fasting in Islam) in Ramadhan month and as music instrument accompanying certain music ensemble (okol and glundhângan) (see, Bouvier, 2002: 42-48).

Tradition of dhârâ ghettakan cannot be separated by owning tong-tong instrument. In this case, tong-tong becomes a must owned by every master of ghettakan because it relates to medium of communication among pigeon masters or to their pigeons. There are three kinds of tong-tong often used by some pigeon masters in Jember which are tong-tong perrèng (made of bamboo small sized), dhung-dhung (made of wood big sized) and tongtong ghellung (made of wood bight shaped).

In tradition of dhârâ ghettakan, tong-tong instrument has some important functions. Tongtong cannot be sounded carelessly. There are special times, special rhythms and terms which must be fulfilled before beating tong-tong. Most people know three kinds of tong-tong beats related to tradition of dhârâ ghettakan which are 1) tongtong ngenning (gudul/niter), 2) tong-tong ngonggha aghi (matèngghi), 3) tong-tong pangolok.

Tong-tong ngenning is sounded only when a master succeeds to get pigeon. In this context, it is sounded a typical rhythm from the tong-tong beats to give code and information to people around, especially among pigeon masters that there is a master (beating tong-tong) who just gets pigeons. After sounding tong-tong ngenning, among masters (commonly a community colleagues) are usually coming to the master's house who just gets pigeon to give congratulations and see pigeons he just got.

In Soca Pangepok village, the sign is known as gudulân, if code of tong-tong gudul is sounded, it means that tonight there will be nyata celebration and players of glundhângan orchestra must be ready to carry instruments to the master's house who just gets pigeons (Sup, personal communication in $29^{\text {th }}$ December 2018 in Soca Pangepok, Jember). On the other side, tong-tong ngening also means a mock to a lost master (loosing pigeons). Sounding tong-tong ngening means someone who loses pigeons has been humiliated in front of villagers. Tong-tong ngening beats in this case can mean as glorification beats (victory beats).

Tong-tong ngongghâaghi has different dimension from tong-tong ngening. As illustration, here is narration in ethnographic notes:

"About 12 p.m., mas Budi informs me that he will hold ritual ngongghâa-aghi dhârâ (elevating pigeon). At first, he goes to behind house, precisely to kitchen, he takes big sized dhung-dhung and its bat with its tip bandaged by used rubber tires. Before beating, he reads mantra and prayer then blows the bat he holds with mantra red before. Mas Budi beats dhung-dhung with dynamic rhythm, slowly then hard for 1 minutes. Pigeons above pajhudhun 5-meter height chirps to each other as if replying rhythm beat of the dhung-dhung. In the morning, mas Budi releases a swarm of pigeons. The pigeons swarm flies around pajhudhun roof, longer and higher then finally return home by bringing a new pair of pigeons suspected loosen from their master. Mas Budi succeeds to catch and then sounds dhung-dhung ngenning which signs that he has got new family" (Ethnographic notes in $12^{\text {nd }}$ February 2019 in Kalisat, Jember).

Illustration above describes that tong-tong ngonggha aghi is tied to ritual work of a master with his pigeons. Rhythm sounded by tong-tong functions as medium of communication between master and his pigeons. The rhythm is believed by masters to be able to hypnotize and deliver prayer (mantra) to pigeons through sound vibration of tong-tong. Rhythm sound is intended to make pigeons fly higher (ongghâ) and faster than usual. Tong-tong ngonggha aghi is only done in the night between $12 \mathrm{pm}$ to $2 \mathrm{am}$, and accompanied by reading prayer and mantra to pigeons.

The last beat is tong-tong pangolok. This beat also has same dimension to ngongghâ aghi beat. Tong-tong pangolok is only sounded by pigeon master when his pigeons fly too far or fly away (not returning home). Sounding this beat is also accompanied by reading prayer and mantra before 
so that the pigeons in far distance can feel vibration of tong-tong pangolok sound. Sometimes some masters who use tong-tong pangolok is considered as cheating by people, like calling some of his pigeons which has been sold to other people few years ago (Budi and Salam, personal communication in $22^{\text {nd }}$ January, in Jatian, Kalisat, Jember). This common thing happens in society because pigeon has strong instinct to its master. If a new master cannot treat and train it well, the pigeon often flies and return back to its former master.

Tong-tong and dhung-dhung which are peculiar and identical to tradition of dhârâ ghettakan become a must and important instrument in ensembele music of glundhângan. Therefore glundhângan is always related to dhârâ ghettakan. Instead of metallophone gamelan which has many functions in Madurese people like accompanying music for wedding, tabbhuwân ketoprak and ludruk, glundhângan only functions for dhârâ ghettakan event. If a glundhângan group is invited, they cannot be separated to their pigeon community. In context of dhârâ ghettakan tradition, glundhângan is functioned to various things and events which are totta'an dhârâ, nyata, and arisan.

In case of totta'an, glundhângan functions as entertainment and accompanying music for pigeon release. Before totta'an begins, tabbhuwân glundhângan players have been in location of match and play some repertoire of Madurese songs in order to welcome pigeon masters from two communities. Tabbhuwân glundhângan is usually invited by host of totta'an event or by agreement of two communities. When pigeons release begins, tabbhuwân glundhângan plays tense and ambient music. It functions to build adrenaline and emotion of masters who fight. In case of pigeon's release, glundhângan music functions as accompanying music of match like martial art, ojhung, and okol. The masters' emotion which peaks when watching their pigeons fly random and mixed with opponent's pigeons in the sky, then is dramatized and stirred by music strains of tabbhuwân glundhângan. So it creates war atmosphere among masters. All cheers, snaps, berates even mocks opponent's pigeons when they cannot fly following their colony and all is laughing together with glundhângan music.
A master who succeeds to win in tottain event or succeeds to get pigeons ouside tottáan event, after sounding tong-tong ngening, he will hold nyata event as winning manifestation. Nyata is celebration moment when a master succeeds to get pigeons in his pajhudhun. It is held in the night by inviting neighbors and relatives among pigeon community members in village with entertainment of glundhângan music. In Soca Pangepok village, nyata event is still often done by people remembering that almost every house has pajbudhun and raise ghettakan pigeon.

In a night, $29^{\text {th }}$ December 2018, I am accompanied by Ju' Salam (elders of glundhângan), mas Sup (glundhângan player), Yongki and Cak Lip to look a set of ancient glundhângan instruments in Mr. Di house. Some days ago in Mr. Di, nyata event is just hold. He just gets some pigeons. The glundhângan instruments are still in his house and not returned yet. According to Ju' Salam, nyata event means as sign if there is a master who succeeds to get pigeons. Ju' Salam and his friends play glundhângan in nyata event voluntarily and not by order. It

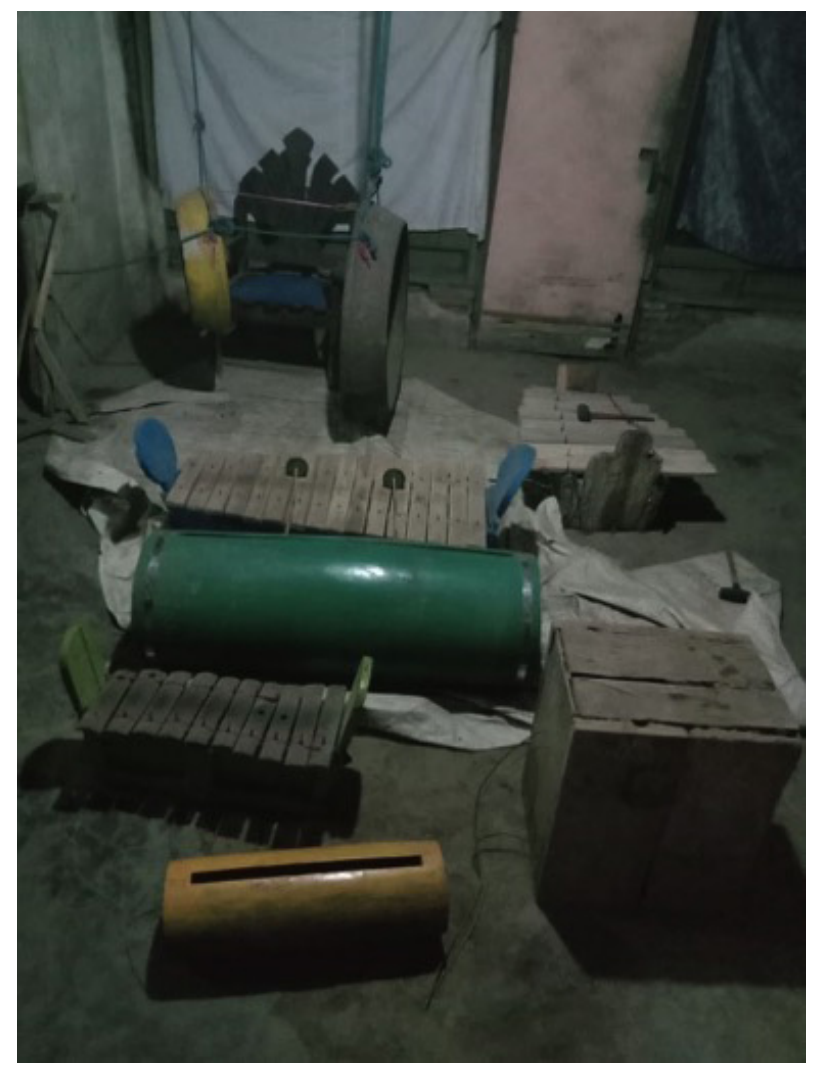

Figure 2. A set of tabbhhuwân glundhângan in Soca Pangepok. (Source: personal documentation) 
has been a tradition if there is nyata event in village so Ju' Salam and friends must be ready to play glundhângan in master's house to appreciate him" (Ethnographic notes in $29^{\text {th }}$ December 2018 in Soca Pangepok village, Jember).

Glundhângan players in Soca Pangepok village, among them, actually do not raise ghettakan pigeon. They are just loyal to serve villagers who hold nyata event. They usually play from $7 \mathrm{pm}$ to dawn without being paid. Playing glundhângan in nyata event can be interpreted as kind of appreciation of village artists to a master's greatness who has succeeded to get pigeons.

Glundhângan music in case of nyata is glorification music, which signifies a victory and means as a mock to a lost master. Ju'Salam says that a lost opponent is often angry and emotional because he feels ashamed by nyata celebration. $\mathrm{He}$ must be planning something to avenge his defeat and when he gets a chance to get pigeon (even only one), so he will avenge by holding nyata celebration too. Sometimes cost spent for nyata event is much higher than a cost of pigeons got (Ju' Salam, personal communication in $29^{\text {th }}$ December 2018). In nyata event, a master must give food to neighbors and relatives who come. Therefore, nyata and glundhângan are not only just celebration of victory but also distribution of existence desire (prestige) and pride at stake for Madurese people.

The next context is glundhângan in pigeon community arisan/gathering. Most pigeon communities in Jember have a set of glundhângan instruments with set of loudspeaker. Glundhângan music is played during arisan event from 8 am until 12 am. For example Merpati putih community, led by Mr. No di Keranjingan, every Sunday holds arisan gathering by using glundhângan entertainment and is broadcasted through loudspeaker.

"In sunday morning, 30 ${ }^{\text {th }}$ December 2018, at $08.00 \mathrm{am}$, I go to arisan location in Mr. Taufik's house in Keranjingan with Mr. Jamhari (glundhângan player). In the location, there is a host and a soundman (sound operator) who prepares microphones to each glundhângan instruments. Mr. Jamhari starts to arrange the instru- ments. One by one member gathers and plays glundhângan alternately. It is a bit different to glundhângan in Soca Pangepok. Here, glundhângan music is mixed to other music set like kendang Banyuwangi, saron and gong. Here, it has no more used tong-tong instrument because of efficiency to bring it. They play songs of Banyuwangi, Javanese, gending Jaranan and sometimes play Madurese dangdut entitled Okossa Menynyan. They don't stop playing until eating together and arisan event are finished" (Ethnographic notes in $30^{\text {th }}$ December 2018 in Keranjingan, Jember).

Glundhângan group in Keranjingan has different style with in Soca Pangepok. If in Soca Pangepok, its character is dominated by Madura, in Keranjingan, its form has been assimilated. This can be understood because Soca Pangepok is suburb and mountain area which has difficult access to reach while Keranjingan is near city so that interaction process of inter-culture goes dynamically. In arisan context, glundhângan music has function as means to interact among masters in a pigeon community. Glundhângan also becomes entertainment and accompanying music in pigeons release in arisan event.

\section{Glundhângan Music and Pigeon as Way of Communication in Sociocultural Relation}

In case of social relation of Madurese people, glundhângan music and dhârâ ghettakan tradition can be red as media of symbolic communication. As Geertz reads culture as a text connected to net of symbolic meanings, he needs deep and comprehensive interpretation of cultural subjects. Context of glundhângan music and pigeon in Madurese society can be interpreted as expression to represent social degree. Tradition of dhârâ ghettakan is closely related to fight of affection power. Social degree in society is signed by how dominant/strong existence of pigeon master in society. A master who can win every match of dhârâ ghettakan (totta'an dhârâ or usullay gets opponent's pigeons) will get acknowledgement from people for his great power. To win a match, every master prepares himself by sharepening his affection power, training pigeons 
with certain mileage and intensely raising pigeons. Winning a match of ghettakan pigeon is the same as winning a fight of affection power among pigeon masters (human). In this case, pigeon is only as media of distributing masters' desire to fight each other.

Having affection power (ajian) is a special prestige for matsers. For them, the higher affection power, the more he gets respected and honored by people around. As mas Budi's story bellows.

"Among pigeon masters are competing their power, the more ajian he has, the higher and deeper his power is, and therefore he will win a match. We can look ajian mastered by master through how pigeon flies. Here, ajian commonly used is dhâddhâli potè. If master uses this ajian, his pigeons can form like formation of eight number and fly lamsam (slowly). If an opponent also uses the same ajian, so affection power will fight. A master who is hard-working (tirakat) and often tangngi malem (not sleeping in the night for tirakat), he will win. A lost master is one whose pigeons are influenced by opponent's pigeons colony and joining their colony. Besides, ajian dhâddhâli potè, there is one more ajian used to dhârâ ghettakan which is ajian poter giling. This is the most strong ajian but dangerous to practice because a master will get severe consequences which is karas, which means his worth will not be blessed, quickly gone and never satisfied. All my pigeons here are used poter giling, but it is not me who practices, but my mother. This ajian was used by my grandfather, then now it is inherited to his descendant. A person who practices ajian poter giling is usually old because they are not burdened by worldly things. For me, I still hesitate to practice ajian poter giling. This ajian is practiced by sellekkan (through food) and tong-tong matèngghi. Pigeons filled by ajian poter giling will have typical fly. At the beginning, they will fly straight fast and suddenly lost. A few minutes later, they fly down from height by spinning above their pajhudhun. My pigeons are often appreciated by people for their way to fly.
They know if my pigeons are used ajian poter giling. An advantage of practicing poter giling is ekasengkaè orèng (respected by people)" (Budi, personal communication in $12^{\text {nd }}$ in Kalisat, Jember).

Mas Budi explanation illustrates that every master will strengthen his soul by mastering affection power. There are two affection powers usually practiced by pigeon master which are dhâddhâli potè and poter giling. These two powers are actually common to use to humans. Use of affection power will effect to how pigeons fly. People then sign or value a master's affection power by how his pigeons fly. A master who practices ajian dhâddhâli potè will be shown by how pigeons fly and form formation like eight number and fly slowly. Meanwhile, a master who practices ajian poter giling will be shown by how pigeons fly straight fast and then lost, and a few minutes later, they fly down from height by spinning above their pajhudhun. The higher his affection power, the more he is respected and honored by people.

A fight of affection power in tradition of dhârâ ghettakan is used in two ways. First is practicing affection power for his pigeons. The second is practicing affection power to attack opponent's pigeon. Use of affection power as explained in the first is used by a master through sellekkan (food) and sound tong-tong matengghi. The second use of affection power has similarity to use it for human. The second way is called sèpèr (nyèpèr) to take opponent's pigeons targeted. Mas Budi and Mr. Salam tells process of sèpèr in tradition of dhârâ ghettakan as follows.

"If we want to take opponent's pigeons, we have to know first opponent's weakness when he is slack. It is the same when we want to manèser (influence to love) a woman when she is in period. A master who often sleeps in the night and rarely tirakat will be easily defeated. Meanwhile, a master who rarely sleeps is hard to defeat. We must know when he is slack. When we have known his weakness, we just practice affection power and then first attack is to the master, not his pigeons. If the master has been influenced by affection power, his 
pigeons must be influenced too. Pigeon has inner connection with its master. If the master is hard to defeat, then next we attack his wife. There are two possibilities which are attacking the master or his wife. In practicing affection power, we have to mention a kind of pigeon targeted in prayer (mantra) for example khususan dhârâ ghet merah or dhârâ paol. I often used to do it. After three days of practicing, usually there will be a sign of dream. There are two guests coming. In the morning, it is true that there are two pigeons I target which come to my pajhudhun" (Budi and Salam, personal communication in $22^{\text {nd }}$ January 2019, in Jatian, Kalisat, Jember).

The illustration above signifies competition and fight among masters of ghettakan pigeon not only in totta'an dhârâ arena but also in daily life. In daily life, masters actually live friendly and look common like common people who are not conflicting, but in case of pigeons, they look competing each other. Some informants said to me that they are friend among masters but being competitors only in pigeon tradition (moso dhârâ). The statement causes suspicion that actually there is something veiled they intend to hide. They do not show enmity nuance in reality but competition only shows through media of pigeon. Every master is standby every night (does not sleep and tirakat), for guarding if there is a master attacking his pigeons colony. A fight of affection power in tradition of dhârâ ghettakan is only limited to media of pigeon (not human). It means that there is rarely practice to harm physically pigeon's master and his family. Keeping pigeon's loyalty, winning a match and seize opponent's pigeon are strategies of every master to form his existence and effort to elevate his social degree in society. So no wonder, if in Soca Pangepok, there are people who raise pigeons with more than one pajhudhun and often hold nyata because the more pigeons they have means the higher guts they have. When a master often wins a match means that he gets high social degree in society.

Glundhângan music and tradition of dhârâ ghettakan can also be interpreted as a fight of pride and manifestation of masculinity of Madurese people. In Soca Pangepok village, tradition of raising ghettakan pigeon lives as a necessity. It will be a taboo for people especially men who do not raise ghettakan pigeon. Ju' Salam and mas Sup often get insinuated among their friends in village for not raising pigeons.

“ $E$ ka'ento mon ta' bengal ngobu dhârâ nèka ècokoco, kaulâ segghut ekoca' bhâreng kanca, 'arèya bengkona randhâ ye!!', ekoca' bengkona randhâ polana sobung pajhudhun-na, artèna sobung lalakèna, otabâ ta' bengal ka rèsikona ngobu dhârâ" (Sup and Ju' Salam, personal communication players in $29^{\text {th }}$ December 2018 in Soca Pangepok, Jember).

(Here, someone afraid of raising pigeon will be insinuated. I often get insinuated by my friends, "is it a widow's house?". It means that a house with no pajhudhun is no brave men taking a risk to raise pigeons)

Not raising pigeon in Soca Pangepok village means that he is not real gentleman because he is afraid of risk. So there is a term 'widow's house'. Raising pigeon is known as full of risk because it is required to go down to fight arena, not only pigeons fight but also affection power. Madurese people commonly live with full of risk and like a challenge. Therefore if a man is afraid of raising pigeons with full of its risk, commonly he does not deserve to call as a real gentleman.

Fight of pride and honour looks clearly in nyata celebration involving glundhângan music. The crowder nyata event, the bigger pride he gets. For some people considered to be public figures in Soca Pangepok village, they sometimes willingly spend money, a few million rupiahs, to hire tandầ bini' (woman dancer and singer) to perform in nyata event"(Sup and Ju' Salam, personal communication players in $29^{\text {th }}$ December 2018 in Soca Pangepok, Jember). By economic calculation, nyata event is actually not profitable for a host. Pigeons price he gets do not equal to cost spent by a host but there is another cultural value achieved by means of nyata celebration. Nyata is a language of pride and pride at stake for master of ghettakan pigeon. Therefore it becomes a necessity to hold.

Like tradition of cow fight and cow race for Madurese people, tradition of glundhângan and dhârâ 
ghettakan is a means of distribution of conflict desire among humans productively. This tradition emerges because of incapability of people to confront directly and physically. In Madurese culture, there is a term, carok as solution model of physical conflict. Based on Wiyata (2002: 103) research, carok usally can happen because of a few things which are when a wife is disturbed, problem of land legacy, debts, politeness and other intercommunication. From many cases, susceptible case which often happens and emerges is conflict of disturbed wife. Disturbing somone's wife for Madurese people means playing her husband's pride and causing a shame (malo), so the husband deserves to fight (carok). A shame emerges as consequences of people's treatments which deny and do not respect someone's capacity (Wiyata, 2013: 17).

Tradition of dhârâ ghettakan comes as a turn of desire of fight for Madurese people. Instead of fight directly like carok, tradition of dhârâ ghettakan represents a fight among humans symbolically by means of pigeons. The conflict which often happens in Madurese people like disturbed wife is manifested in dhârâ ghettakan. Pigeon in tradition of dhârâ ghettakan is symbolized as feminine subject like a wife. A pigeon's master regularly gives affection mantra/prayer to his pigeons like to a woman he loves. He is also required to maintain inner connection to make his pigeons keep loyal to him and cannot be influenced by other masters. Even in some moments like a night before totta'an dhârâ event, a master is willing to accompany his pigeons to sleep in pajhudhun. In dhârâ ghettakan pigeon, a fight is about degree of pigeon's loyalty like how a Madurese man keep his wife's loyalty. Domination of a master to his pigeons is like domination of a man to his wife. Concept of a gentleman who has a pride in Madurese culture is that he can keep his wife and willing to sacrifice himself when his wife is disturbed by other people. In tradition of dhârâ ghettakan, conflict and competition in seizing and defending pigeon's loyalty are not practiced through physical violence (carok) but by means of totta'an dhârâ. Therefore, it can be said that tradition of dhârâ ghettakan and glundhângan music in Madurese people are efforts to distribute desire of conflict among humans productively.

\section{Conclusion}

Tradition of dhârâ ghettakan in Madurese people until now is still alive and develops in Jember. Raising pigeon is related to people's belief of pigeon myths like ghettakan pigeon can protect someone's house from devil's attack, pigeon can bring blessing because it is believed praying for its master in the night and can elevate social degeree of person. In case of social degree, pigeon can be treated as media to express a fight among masters. The fight is manifested in totta'an dhârâ. In totta'an dhârâ, there is no money gambling or physical fight of male animal like cow fight but it is a fight of loyalty between pigeon and its master. Contestation in totta'an dhârâ arena is symbolic manifestation of fight among masters who fight their affection power. Pigeon in Madurese people's mindset is put as feminine symbol. Therefore relation between Madurese man and ghettakan pigeon is manifestation of masculine domination of Madurese people.

Tradition of dhârâ ghettakan is closely related to tong-tong and glundhângan music. Tong-tong and glundhângan music function as medium of communication of master to his pigeons and people around. Tong-tong instrument is sounded in three events with different rhythm, which are 1) tong-tong ngenning (niter), when getting pigeon; 2) tong-tong ngongghâ aghi (matèngghi), when having ritual of elevating pigeon and 3) tongtong pangolok when calling pigeon. Glundhângan music is a bigger form (ensemble) of tong-tong music. Glundhângan in nyata celebration means as glorification music for a master who gets pigeon and as mockery music to a lost master who loses his pigeons. Glundhângan in totta'an event means entertainment and accompanying music for match while glundhângan in arisan/gathering event means as entertainment music and means of interaction among pigeon masters. Therefore, glundhângan and pigeon can be red as ways of communication of Madurese people in social relation. Glundhângan music and pigeon are articulations of Madurese people which represent social degree, pride at stake, symbol of masculinity and distribution of conflict desire among humans productively. 
Condition of glundhângan music and tradition of dhâra ghettakan today have been developing and having alternative functions in society like for introductory entertainment in wedding event, orderd entertainment, general election campaign, complement of ceremonial event, entertainment in inauguration event and entertainment in various release events.

Glundhângan music in case of nyata is glorification music, which signifies a victory and means as a mock to a lost master. Ju'Salam says that a lost opponent is often angry and emotional because he feels ashamed by nyata celebration. He must be planning something to avenge his defeat and when he gets a chance to get pigeon (even only one), so he will avenge by holding nyata celebration too. Sometimes cost spent for nyata event is much higher than a cost of pigeons got (Ju' Salam, personal communication in $29^{\text {th }}$ December 2018). In nyata event, a master must give food to neighbors and relatives who come. Therefore, nyata and glundhângan are not only just celebration of victory but also distribution of existence desire (prestige) and pride at stake for Madurese people.

The next context is glundhângan in pigeon community arisan/gathering. Most pigeon communities in Jember have a set of glundhângan instruments with set of loudspeaker. Glundhângan music is played during arisan event from 8 am until 12 am. For example Merpati putih community, led by Mr. No di Keranjingan, every Sunday holds arisan gathering by using glundhângan entertainment and is broadcasted through loudspeaker.

\section{References}

Arifin, Edy Burhan. (2006). "Migrasi Orang Madura dan Jawa ke Jember (Suatu Kajian Historis Komparatif)". Jurnal Ilmu SejarahHistoria, 3(1)

Bourdieu, Pierre. (1984). Distinction: A social Critique of the Judgement of Taste. Massachusetts: Harvard University Press

Bouvier, Hélèn. (2002). Lèbur!: Seni Musik dan Pertunjukan dalam Masyarakat Madura. Jakarta: Yayasan Obor Indonesia.

Buys, Brandts, van Zijp, J. . \& A. (1928). De
Toonkunst Bij De Madoereezen, (Jawa VIII). Weltevreden.

Bishop, C.W. (1925). "The Ritual Bullfight”, The China Journal of Science and Arts 3: 630-637 in Jounge, Huub De. 2011. Garam, Kekerasan dan Aduan Sapi: Essai-Essai Tentang Orang Madura dan Kebudayaan Madura. Yogyakrta: LKIS.

Geertz, Clifford. (1973). The Interpretation of Culture. New York: Basic Books inc.

Hidayatullah, P. (2017). Dangdut Madura Situbondoan. Yogyakarta: Diandra Kreatif.

Husson, Laurence. (1997). "Eight Centuries Of Madurese Migration to East Java”. Asian and Pasific Migration Journal, 6(1).

Irmawati, Rosida. (2004). Berkenalan dengan Kesenian Tradisional Madura. Surabaya: Penerbit SIC

Jounge, Huub De. (2011). Garam, Kekerasan dan Aduan Sapi: Essai-Essai Tentang Orang Madura dan Kebudayaan Madura. Yogyakrta: LKIS.

Kreemer, J. (1956). "De Karbouw: Zijn betekenis voor de volken van de Indonesische studie. Emmerik a.d. Rijn: Urban Schmitz. (PhD Thesis Hoogeschool, Utrecht) in Jounge, Huub De. 2011. Garam, Kekerasan dan Aduan Sapi: Essai-Essai Tentang Orang Madura dan Kebudayaan Madura. Yogyakrta: LKIS.

Munardi, A.M., Koesdiono dkk. (1983). Pengetahuan Karawitan Jawa Timur, Jakarta: Dep. P. dan K in Bouvier, Hélèn. 2002. Lèbur! Seni Musik dan Pertunjukan dalam Masyarakat Madura. Jakarta: Yayasan Obor Indonesia.

Prasisko, Yongky. G. (2015). Blandongan: Perebutan Kuasa Budaya Masyarakat Jawa dan Madura. Yogyakarta: Lembaga Penelitian Rekonsiliasi dan Integrasi Sosial.

Santosa, Imam Budhi. (2017). Profesi Wong Cilik: Spiritualisme Pekerjaan-Pekerjaan Tradisional. Yogyakarta: Basabasi.

Setiawan, A. (2018). Arkeologi Gamelan di Sumenep: Dari Imaji Masyarakat Akar Rumput tentang Gamelan Hingga Penelusuran Gamelan Langka Dengan Berbagai Problematiknya. Surakarta: ISI Surakarta.

Wiyata, L. (2002). Carok: Konflik Kekerasan dan Harga Diri Orang Madura. Yogyakarta: LKIS 
Wiyata, L. 2013. Mencari Madura. Jakarta: BidikPhronesis Publishing.

\section{Informant}

Ihsan (about 60 years). Master of ghettakan pigeon in Soca Pangepok.

Fauzi (about 60 years). Master of ghettakan pigeon in Situbondo.

Kernet (about 30 years). Teacher in Sakola Kaki Gunung Sokma Elang Jember.

Budi (about 30 years). Master of ghettakan pigeon in Kalisat Jember.
Mr. No (about 60 years). A chief of white pigeon community in Keranjingan-Kebonsari Jember.

Taufik (about 30 years). Member of white pigeon community and master of ghettakan pigeon in Keranjingan - Kebonsari Jember.

Edi (about 30 years). Master of ghettakan pigeon in Keranjingan Jember.

Ju' Salam (about 70 years). Glundhângan player in Soca Pangepok.

Sup (about 40 years). Glundhângan player in Soca Pangepok.

Salam (about 50 years). A master and trader of ghettakan pigeons. 